\title{
Adaptability to energy, production efficiency and the crude oil price: evidence from a small open economy
}

\author{
C.-H. Huang ${ }^{1}$, H.-P. Su ${ }^{1}$, C.-W. Yang ${ }^{1}$, C.-Y. Hong ${ }^{2}$ \& J.-F. Li ${ }^{2}$ \\ ${ }^{I}$ Taiwan Research Institute, Taiwan \\ ${ }^{2}$ Department of Finance, Chaoyang University of Technology, Taiwan
}

\begin{abstract}
Taiwan is an economy which is highly dependent on energy imports. A change in oil price not only affects the cost of production, but also the economic growth. Since the year 2000, the crude oil price has risen and become an unstable factor for economic development. In response to the rapid rising of emerging economies and the competitive international economic environment, Taiwan is facing a moment of industrial restructuring. Energy-saving technologies and improved efficiency might play important roles. It is necessary for Taiwan to improve its industrial productivity and production technology to contribute to the global warming problem. From crude oil intensity and change in spillover effects of crude oil price, we might detect whether industrial production efficiency and adaptability to energy and production technology improves or not. Based on the input - output table showing the monetary value of inputs to each sector and each row represents the value of each sector's outputs during the periods of 1981 to 2011 , the present study employs the industry-related price model and factor decomposition model to investigate the change in Taiwan's reliance on crude oil through crude oil intensity. Although efforts have been made to advance technology and improve energy dependence, the results of this study indicate that imported crude oil intensity and price responsiveness have actually increased. Thus, the speed of improvement in energy technology is insufficient to keep up with the extent of economic growth.

Keywords: industry-related price model, production efficiency, crude oil price, imported crude oil intensity.
\end{abstract}




\section{Introduction}

After two crude oil crises in the 1970s, which upset the economy in Taiwan, the international prices of crude oil remained relatively stable, driving Taiwan's economic development. Following the year 2000, international crude oil prices rose gradually, peaking in July 2008 before beginning to fluctuate wildly. These price increases differed from those during the oil crises in the 1970s. Newly industrialized countries and an expanding global supply chain are driving the rapid growth in crude oil demand. In addition, the development of international financial markets is also increasing speculative demand in the crude oil market.

Taiwan lacks crude oil production, depending almost entirely on imports to supply various economic activities. The stability of crude oil prices influences production costs and has become a key factor in its economic development, affecting its future economic growth. Since Taiwan experienced both the oil crises and its economic boom in the 1990s, the government and businesses have been investing heavily in new energy technology, endeavoring to adjust the industrial structure. After Taiwan joined the World Trade Organization (WTO) in 2002, trade liberalization expanded the scale of international trade, increasing domestic production and exports and fueling the demand for international crude oil. Irrespective of this, overall industrial energy intensity has improved gradually, falling from 9.45 (liters of oil equivalent (LOE)/NT $\$ 10^{3}$ ) in 2003 to $7.52\left(\mathrm{LOE} / \mathrm{NT} \$ 10^{3}\right)$ in 2014 . The energy intensities of the three main sectors which are the agricultural sector, the industrial sector, and the service sector, fell from $7.4\left(\mathrm{LOE} / \mathrm{NT} \$ 10^{3}\right), 18.9\left(\mathrm{LOE} / \mathrm{NT} \$ 10^{3}\right)$, and $1.6\left(\mathrm{LOE} / \mathrm{NT} \$ 10^{3}\right)$ in 2003 to $5.0\left(\mathrm{LOE} / \mathrm{NT} \$ 10^{3}\right), 12.4\left(\mathrm{LOE} / \mathrm{NT} \$ 10^{3}\right)$, and $1.4\left(\mathrm{LOE} / \mathrm{NT} \$ 10^{3}\right)$ in 2012, respectively. However, compared with that of other advanced countries, Taiwan's crude oil intensity remains high.

Whether Taiwan's energy efficiency would improve with economic development remains unknown. The efforts of the government and businesses are evident in the annual decline in domestic energy intensity. However, the sustainable development of a country's economy relies on improvements in energy-saving technologies and the efficient response to changes in the international economic environment and to industrial restructuring.

Considering the aforementioned concerns, in the present study, we examined the influences of changes in international crude oil prices on industry costs and prices over a period during which international crude oil prices doubled. Improvements in industrial crude oil utilization technology were investigated from the perspectives of quantity and price. To achieve these objectives, we used the industry-related price model, estimating the imported crude oil intensity of final demand for a quantity analysis and the responsiveness of the domestic price toward crude oil price. These analyses facilitated observing the changes in crude oil dependence by Taiwanese industries and the responsiveness toward crude oil prices over 30 years.

In 2008, the global financial crisis severely affected the economies of Europe and North America. Because nearly 70\% of Taiwan's economic growth depends on trade, Taiwan could not evade the impact of the crisis. The capital transfers 
that accompanied the financial crisis accelerated a rapid rise in international crude oil prices, compounding Taiwan's economic difficulties. Unlike most previous studies conducted in Taiwan that used domestic energy intensity to address dependence on crude oil, in the present study, we employed the import intensity of final demand to investigate the dependence of Taiwanese industries on crude oil imports. A factor decomposition model of import intensity was used to explore factors affecting dependence, enabling us to determine indirectly Taiwan's long-term industrial restructuring. We used the price responsiveness to crude oil output to analyze the response of domestic production costs and prices to changes in international crude oil prices. In addition, a factor decomposition model was also applied to uncover the factors affecting the responsiveness to crude oil prices. These methods contrast with those of literature (i.e., primarily using statistical methods to estimate energy price elasticity). The results in the present study could afford an understanding of the properties and production technologies of various industries in Taiwan.

\section{Literature review}

The two oil crises confirmed that economic growth worldwide is overly reliant on oil. Numerous studies have revealed that fluctuations in energy prices result in substantial economic losses (Hamilton [1]; Davis and Haltiwanger [2]; Lee and $\mathrm{Ni}$ [3]). This phenomenon has not changed in the twenty-first century because the economic growth of newly industrialized countries has substantially increased energy demand, prompting speculation in energy futures markets and also increasing the instability of international energy prices (Blanchard and Gali [4]; Hamilton [5, 6]). In addition, to maintain continued economic growth, newly industrialized countries respond to rises in crude oil prices by implementing subsidies. Studies have applied energy price elasticity to investigate the relationship between energy demand and prices In particular, numerous studies have explored the price elasticity of China's energy demand or changes in income elasticity (Asadoorian et al. [7]; Ma et al. [8]; Lin and Jiang [9]). Because globalization has developed rapidly, exchange rates have also become a major factor influencing energy prices and increasing the impact on energy prices (Kilian and Park [10]; Fukunaga et al. [11]).

Economic development and globalization have destabilized international energy prices. Some studies have documented the effects of changes in crude oil prices on economic development and societies from various perspectives, focusing on the extent to which asymmetries in energy price elasticity have affected economic growth rates and domestic prices. Price asymmetries can be used to estimate the direction of changes in economic variables (Gately and Huntington [12]; Adeyemi and Hunt [13]; Ma et al. [8]; Inglesi-Lotz [14]; Neto [15]). Alternatives between factors of production have also been used to analyze asymmetries (Roy et al. [16]).

Studies on the impact of increases in crude oil prices on the macroeconomy could be divided into empirical analyses and predictive analyses. Empirical analysis primarily involves using the vector autoregressive (VAR) model for 
inference, whereas predictive analysis involves using economic theory as a basis for estimating the ripple effects of economic booms. The econometric model was popular in the 1980s for analyzing the effects of crude oil price changes (Hickman et al. [17]). Beenstock [18] examined developing countries that imported oil, applying a macroeconometric model to analyze the influence of increases in crude oil prices on import prices and production costs. In addition, multiple studies have analyzed the relationship between changes in crude oil prices and changes in economic cycles (Kim and Loungani [19]; De Miguel et al. [20]).

Burbidge and Harrison [21] documented the relationship between macroeconomic changes and crude oil prices. Mork [22] examined the influence of fluctuations in crude oil prices on GDP, observing asymmetries between the two. The results of a study by Mory [23] supported this conclusion. Lee et al. [24] used the generalized autoregressive conditional heteroskedasticity model to analyze volatility in crude oil prices and confirmed the presence of asymmetries. The relationship between crude oil prices and macroeconomic indicators was investigated by Hooker [25], who confirmed Granger causality between the two; Hamilton [1] confirmed this conclusion. According to the premise that the relationship between crude oil prices and GDP is nonlinear, Hamilton [5] performed econometric analysis. Bernanke et al. [26] indicated that appropriate financial policies could be implemented to reduce the impact of crude oil prices. Balke et al. [27] used the VAR model to analyze asymmetries in crude oil prices and indicated that adjustment costs and financial policies cause asymmetries. However, Hamilton and Herrera [28] reported contrasting results. Dalsgaard et al. [29] and Hunt et al. [30] documented the influence of changes in international crude oil prices on the global economy, estimating that the elasticity values of each country's GDP in response to oil prices were between -0.01 and -0.02 . Bohi [31] maintained that rises in energy prices reduce enterprise production and GDP; this reduction is attributable to the direct impact and the indirect influence of capital and labor substitution effects.

Numerous studies have also examined the influence of changes in international crude oil prices on industrial production and prices (Nagano [32]; Klein et al. [33]; Ono [34]; Fuzikawa et al. [35]; Fukunaga et al. [11]).

Klein et al. [33] employed the industry-related price model to estimate the reaction of price indices in U.S. to crude oil prices over the years. He has shown that there were $10.5 \%$ in $1977,3.8 \%$ in 1987 , and $3.3 \%$ in 1997. It indicated that from 1977 to 1997 , the influence of change in crude oil prices on price levels in U.S. gradually reduced. Nagano [32] documented that as crude oil prices increase by $\$ 10$, the average output of mining industry in Japan declines by $0.4 \%$, and the consumer price index increases by $0.09 \%$.

Ono [34] highlighted if crude oil prices increase by $39 \%$, the total output value of industry in Japan would be reduced by $0.36 \%$. Ono indicates that the fiber industry would be the most affected (reduced by $9.81 \%$ ), followed by the petroleum products industry (reduced by $1.90 \%$ ) and the personal services industry (reduced by $1.12 \%$ ). He also found that the consumption would be reduced by $0.65 \%$, investment by $0.38 \%$, and exports would by $0.02 \%$. 
Fuzikawa et al. [35] employed industry-related model to calculate the dependency on crude oil imports in Japan and U.S., and estimate the impact of volatilities in crude oil prices on price levels in the two countries. Results show that after the oil crisis, dependency on crude oil imports decrease in U.S. and Japan. Price indices are also less influenced by fluctuations in crude oil prices. The reason for this might be that Japan is particularly effective in reducing investment in crude oil imports and improving domestic production efficiency. Although the improvements in production efficiency in U.S. do not match those of Japan, U.S. also achieves significant results in reducing investment in crude oil.

\section{Empirical model}

The data with every 5 year and every 3 year from 1981-2011 in the present study is drawn from the publication of input-output table compiled by Directorate General of Budget, Accounting and Statistics (DGBAS), Executive Yuan, Taiwan. We attempt to estimate the imported crude oil intensity of final demand and the responsiveness toward crude oil. The following is the empirical model.

\subsection{Imported intensity (crude oil) of final demand}

The measurement of import intensity of final demand $(\overline{\mathrm{m}})$ for individual industry is

$$
\overline{\mathrm{m}}=\operatorname{MA} \bar{x}=\operatorname{MAB} \overline{f_{d}}
$$

Eqn. (1) stands for the imports per final demand production for individual industry in which we would investigate the imported crude oil intensity (including the natural gas) in the present paper. Where $\bar{x}$ represents the final demand production of individual industry; $\mathrm{B}$ is a Leontief inverse matrix. $\mathrm{M}$ and $A$ are imported coefficient and inputs coefficient of individual industry,

respectively. $\overline{f_{d}}$ denotes change in one-unit domestic final demand as the ratio for individual industry as eqn. (2)

$$
(1, \cdots, 1) \overline{f_{d}}=1
$$

\subsection{Factor decomposition model for imported crude oil intensity of final demand}

The intensity of imported crude oil would change as time moving. In order to uncover the change in factors, the difference in two periods of imported inputs intensity of final demand $(\mathrm{d} \bar{m})$ could be stated as eqn. (3) 


$$
\begin{aligned}
& \mathrm{d}^{\bar{m}}=\bar{m}_{(1)-\bar{m}}(0) \\
& =\mathrm{M}(1) \mathrm{A}(1) \mathrm{B}(1) \bar{f}_{d}(1)-\mathrm{M}(0) \mathrm{A}(0) \mathrm{B}(0) \bar{f}_{d}(0) \\
& =\mathrm{M}(1) \mathrm{A}(1) \mathrm{B}(1) \bar{f}_{d}(1)-\mathrm{M}(0) \mathrm{A}(0) \mathrm{B}(1) \bar{f}_{d}(1)+\mathrm{M}(0) \mathrm{A}(0) \mathrm{B}(1) \bar{f}_{d}(1) \\
& -\mathrm{M}(0) \mathrm{A}(0) \mathrm{B}(0) \bar{f}_{d}(1)+\mathrm{M}(0) \mathrm{A}(0) \mathrm{B}(0) \bar{f}_{d}(1)-\mathrm{M}(0) \mathrm{A}(0) \mathrm{B}(0) \bar{f}_{d}(0) \\
& =\left[\mathrm{M}(1) \mathrm{A}(1) \mathrm{B}(1) \bar{f}_{d}(1)-\mathrm{M}(0) \mathrm{A}(0) \mathrm{B}(1) \bar{f}_{d}(1)\right]+\left[\mathrm{M}(0) \mathrm{A}(0) \mathrm{B}(1) \bar{f}_{d}(1)-\right. \\
& \left.\mathrm{M}(0) \mathrm{A}(0) \mathrm{B}(0) \bar{f}_{d}(1)\right]+\left[\mathrm{M}(0) \mathrm{A}(0) \mathrm{B}(0) \bar{f}_{d}(1)-\mathrm{M}(0) \mathrm{A}(0) \mathrm{B}(0) \bar{f}_{d}(0)\right] \\
& =[\mathrm{M}(1) \mathrm{A}(1)-\mathrm{M}(0) \mathrm{A}(0)] \mathrm{B}(1) \bar{f}_{d}(1)+\mathrm{M}(0) \mathrm{A}(0)[\mathrm{B}(1)-\mathrm{B}(0)] \bar{f}_{d}(1) \\
& +\mathrm{M}(0) \mathrm{A}(0) \mathrm{B}(0)\left[\bar{f}_{d}(1)-\bar{f}_{d}(0)\right]
\end{aligned}
$$

where $[\mathrm{M}(1) \mathrm{A}(1)-\mathrm{M}(0) \mathrm{A}(0)] \mathrm{B}(1) \bar{f}_{d}(1)$ is the effects of technology-adjustment of imported input (crude oil); $\mathrm{M}(0) \mathrm{A}(0)[\mathrm{B}(1)-\mathrm{B}(0)] \bar{f}_{d}(1)$ is the effects of efficiency-adjustment in domestic production structure; $\mathrm{M}(0) \mathrm{A}(0) \mathrm{B}(0)\left[\bar{f}_{d}(1)\right.$ $\left.\bar{f}_{d}(0)\right]$ denotes the effects of structure-adjustment for the final demand.

\subsection{Responsiveness of the domestic price toward imported crude oil prices}

Based on the industry-related price model, the responsiveness of the domestic price level $\left(\overline{\mathrm{P}}_{\mathrm{d}}\right)$ to change in imported price of crude oil $\left(\overline{\mathrm{P}}_{\mathrm{m}}\right)$ could be measured by eqn. (4)

$$
\overline{\mathrm{P}}_{\mathrm{d}}=\overline{\mathrm{P}}_{\mathrm{m}}(\mathrm{MA})\left(\mathrm{B}_{\mathrm{d}}\right)
$$

where MA is the coefficient matrix of imported input (crude oil) and $\mathrm{B}_{\mathrm{d}}$ denotes the Leontief inverse matrix.

\section{Empirical results}

\subsection{Changes in imported intensity (crude oil) of final demand}

Overall, Table 1 indicates the ratio of imported crude oil required for every incremental increase in final demand in Taiwan increased from $25.55 \%$ in 1981 to 26.62 in 2011 . However, according to the long-term trends, the year 1981 was just one year after the second oil crisis, during which Taiwan was forced to improve production efficiency and reduce energy dependence. Therefore, industrial restructuring became its economic policy. Between 1986 and 2001, imported intensity decreased annually, indicating that Taiwan's industrial restructuring improved production efficiency. 
Table 1: Imported intensity of final demand.

\begin{tabular}{|l|l|l|l|l|l|l|l|}
\hline Sector & 1981 & 1986 & 1991 & 1996 & 2001 & 2006 & 2011 \\
\hline fishery products & 0.02 & 0.02 & 0.01 & 0.01 & 0.01 & 0.01 & 0.01 \\
\hline other poultry production & 0.08 & 0.08 & 0.05 & 0.04 & 0.02 & 0.01 & 0.01 \\
\hline feed (food for farm animals) & 0.21 & 0.19 & 0.14 & 0.11 & 0.07 & 0.06 & 0.07 \\
\hline crude oil and natural gas & 6.64 & 2.03 & 1.54 & 1.6 & 2.65 & 4.92 & 5.25 \\
\hline petrochemical & 1 & 1.29 & 1.31 & 1.24 & 0.89 & 1.59 & 1.63 \\
\hline chemical fertilizers & 0.08 & 0.03 & 0.02 & 0.02 & 0.01 & 0.03 & 0.04 \\
\hline synthetic fiber & 0.12 & 0.13 & 0.05 & 0.04 & 0.03 & 0.03 & 0.03 \\
\hline plastics & 0.37 & 0.37 & 0.43 & 0.38 & 0.32 & 0.24 & 0.3 \\
\hline petroleum refining & 0.96 & 0.69 & 0.72 & 0.51 & 0.62 & 0.93 & 1.63 \\
\hline transportation & 0.12 & 0.2 & 0.24 & 0.25 & 0.21 & 0.08 & 0.09 \\
\hline pig iron and crude steel & 0.81 & 0.83 & 0.74 & 0.48 & 0.56 & 1.09 & 1.03 \\
\hline electronic products & 0.86 & 1.41 & 1.23 & 2.2 & 3.3 & 0.47 & 3.2 \\
\hline food service & 0.07 & 0.03 & 0.03 & 0.03 & 0.03 & 0.08 & 0.07 \\
\hline hospitality services & 0 & 0.12 & 0.2 & 0.14 & 0.11 & 0.39 & 0.35 \\
\hline electricity & 0 & 0 & 0 & 0.01 & 0 & 0.01 & 0.01 \\
\hline communication & 0.08 & 0.09 & 0.11 & 0.1 & 0.06 & 0.05 & 0.25 \\
\hline financial Industry & 0.02 & 0.03 & 0.02 & 0.03 & 0.03 & 0.03 & 0.12 \\
\hline total Industry & 25.55 & 19.1 & 19.41 & 19.29 & 18.8 & 24.68 & 26.62 \\
\hline
\end{tabular}

Data source: this study.

However, imported crude oil intensity increased substantially between 2006 and 2011, reflecting an increase in Taiwan's import dependence that was caused by a rapid increase in international crude oil prices after 2004. In addition, Taiwan's imports increased substantially after it joined the WTO in 2002. As for the crude oil and gas sector, crude oil import intensity in 1981 was 6.64\%; dependence on crude oil was high compared with that in other industries, but declined substantially between 1986 and 2001, illustrating that the industry's energy efficiency improved slightly.

Nonetheless, the imported crude oil intensity in the crude oil and gas sector again increased substantially between 2006 and 2011, reaching 5.25\% by 2011 . Although we used an input-output table for 2011, we conducted this study in early 2015; thus, there was a gap of more than 3 years, and the current crude oil imported intensity might be even higher.

\subsection{Factor decomposition on changes in imported crude oil intensity}

After the second international oil crisis, as shown in Table 2, Taiwan's imported crude oil intensity fell continually, reaching $1.67 \%$ in 2004 . The decline was most apparent between 1981 and 1984. The factors affecting changes in imported crude oil intensity are technology of imported input, efficiency of domestic production structure, and final demand structure; these factors yielded a $-2 \%,-2.3 \%$, and $-0.3 \%$ contribution, respectively, to the decline in imported crude oil intensity. 
Table 2: $\quad$ Factor decomposition for change in intensity of imported crude oil.

\begin{tabular}{|l|c|c|c|c|}
\hline peffects & $\begin{array}{c}\text { Technology- } \\
\text { adjustment of } \\
\text { imported input }\end{array}$ & $\begin{array}{c}\text { Efficiency-adjustment } \\
\text { in domestic } \\
\text { production structure }\end{array}$ & $\begin{array}{c}\text { Structure- } \\
\text { adjustment } \\
\text { for the final } \\
\text { demand }\end{array}$ & Total \\
\hline $1981-1984$ & -2 & -2.3 & -0.3 & -4.6 \\
\hline $1986-1989$ & -0.09 & -0.49 & -0.11 & -0.69 \\
\hline $1991-1994$ & 0.01 & -0.05 & 7.47 & 7.43 \\
\hline $1996-1999$ & 0.04 & -0.13 & -0.08 & -0.17 \\
\hline $2001-2004$ & 0.78 & 0.18 & 0.61 & 1.57 \\
\hline $2004-2006$ & 0.45 & 0 & 0.97 & 1.42 \\
\hline $2006-2011$ & -1.49 & 3.84 & 2.6 & 4.95 \\
\hline
\end{tabular}

Notes:

1. Data source: this study.

2. The technology-adjustment of imported inputs: the effects resulting from the technology-adjustment of imported inputs. The efficiency-adjustment in domestic production structure: the effects are caused by the change in domestic production structure. The structure-adjustment for the final demand: the effects are from structural change of final demand production.

The most apparent factor in the decline of imported crude oil intensity in 1986-1989, 1991-1994, and 1996-1999 was the structural efficiency of domestic production, yielding a contribution of $-0.49 \%,-0.05 \%$, and $-0.13 \%$, respectively, to crude oil import intensity during each period. In addition, another key factor affecting crude oil import intensity was structure of final demand. With the exception of during 1991-1994, when final demand structure was positive because of the great amount of consumption caused by the economic bubble, final demand structure reduced imported crude oil intensity in 1986-1989 and 1996-1999, yielding contributions of $-0.11 \%$ and $-0.08 \%$, respectively.

Since 2000, newly industrialized economies have grown substantially, driving a rapid rise in crude oil prices. In 2001-2004 and 2004-2006, technology of imported input, efficiency of domestic production structure, and final demand structure all influenced the rise in imported crude oil intensity in Taiwan. These three factors were all positive, indicating that the international economic situation affected Taiwan's economic structure and that Taiwan is an economic entity with high economic uncertainty.

Contributions by efficiency of domestic production structure and final demand structure were positive between 2006 and 2011, increasing imported crude oil intensity. Only improvements in technology of imported input decreased imported crude oil intensity effectively. The global financial crisis of 2007 severely affected the exports of Taiwan, which relies heavily on trade. Imports also declined sharply, causing continual increases in crude oil import intensity. 


\subsection{Changes in responsiveness toward imported crude oil price}

Table 3 reports the sensitivity of domestic prices to changes in crude oil prices. In this study, we assumed that international crude oil prices doubled in the estimation of the impact on domestic prices. The results were as follows:

Between 1983 and 2004, international crude oil prices remained mostly under US $\$ 40$ per barrel. During this period, the sensitivity toward crude oil price was also relatively low. International crude oil prices began climbing rapidly in 2005, peaking at US\$134.78 per barrel in June 2008. The extent to which crude oil prices affected overall industry prices was $1.176 \%$ in 1981 , before the prices declined slightly. However, this increase was not substantial. After 2006, the sensitivity increased, rising to $4.004 \%$ and $7.58 \%$ in 2006 and 2011 , respectively. The increase indicates that domestic prices became more sensitive toward crude oil prices. Sensitivity was 6.448 times higher in 2011 than it was in 1981.

Table 3: Responsiveness of domestic price toward imported crude oil price for individual industries.

\begin{tabular}{|l|c|c|c|c|c|c|c|c|}
\hline Sector & 1981 & 1986 & 1991 & 1996 & 2001 & 2006 & 2011 & $2011 / 1981$ \\
\hline fishery products & 1.528 & 1.390 & 1.116 & 1.101 & 1.694 & 4.981 & 12.678 & 8.296 \\
\hline $\begin{array}{l}\text { other poultry } \\
\text { production }\end{array}$ & 0.278 & 0.246 & 0.295 & 0.318 & 0.387 & 0.753 & 2.075 & 7.471 \\
\hline $\begin{array}{l}\text { feed (food for farm } \\
\text { animals) }\end{array}$ & 0.240 & 0.220 & 0.227 & 0.230 & 0.292 & 0.615 & 1.441 & 5.995 \\
\hline petrochemical & 3.167 & 2.509 & 2.049 & 2.638 & 6.247 & 1.004 & 2.465 & 0.778 \\
\hline chemical fertilizers & 1.661 & 1.035 & 0.608 & 0.558 & 0.894 & 1.902 & 5.084 & 3.062 \\
\hline synthetic fiber & 1.721 & 1.070 & 0.730 & 0.917 & 0.894 & 4.770 & 13.336 & 7.749 \\
\hline plastics & 0.989 & 0.658 & 0.913 & 0.995 & 2.620 & 5.121 & 13.619 & 13.765 \\
\hline petroleum refining & 0.595 & 0.591 & 0.578 & 0.432 & 0.591 & 2.781 & 7.798 & 13.097 \\
\hline $\begin{array}{l}\text { pig iron and crude } \\
\text { steel }\end{array}$ & 0.811 & 0.480 & 0.405 & 0.512 & 0.382 & 1.056 & 2.666 & 3.286 \\
\hline electronic products & 0.376 & 0.234 & 0.203 & 0.265 & 0.322 & 0.783 & 4.199 & 11.181 \\
\hline food service & 0.569 & 0.340 & 0.289 & 0.304 & 0.329 & 1.057 & 3.342 & 5.878 \\
\hline hospitality services & 0.795 & 0.393 & 0.299 & 0.265 & 0.399 & 1.307 & 4.508 & 5.671 \\
\hline air transportation & 3.470 & 2.174 & 1.806 & 2.697 & 2.569 & 6.916 & 20.650 & 5.951 \\
\hline transportation & 0.175 & 0.471 & 0.423 & 0.527 & 0.587 & 1.300 & 3.529 & 20.164 \\
\hline Communication & 0.224 & 0.112 & 0.080 & 0.060 & 0.105 & 0.294 & 1.028 & 4.592 \\
\hline financial industry & 0.085 & 0.107 & 0.070 & 0.045 & 0.058 & 0.170 & 1.026 & 12.038 \\
\hline total industry & 1.176 & 0.789 & 0.854 & 0.602 & 0.756 & 4.004 & 7.580 & 6.448 \\
\hline Data source: this study & & & & &
\end{tabular}

Data source: this study. 
The responsiveness of individual industry toward changes in imported crude oil prices varies. Petrochemical, travel, and transportation industries are the most sensitive. In 2011, air transport had the highest sensitivity (20.65\%), followed by the plastic (13.619\%), synthetic fiber (13.336\%), and fishery (12.678\%) sectors. Comparison of the changes in sensitivity toward oil prices between 1981 and 2011 shows that the sensitivity of the transportation service sector increased the most, growing by 20.164 times, followed by the sensitivities of the plastic and petroleum refining sectors, which grew by 13.765 and 13.097 times, respectively.

\section{Conclusion}

Domestic energy intensity has declined annually. However, imported crude oil intensity has increased. In particular, after Taiwan joined the WTO, a rise in international trade has increased energy dependence to approximately $30 \%-40 \%$. In addition, energy dependence is also reflected in responsiveness toward international crude oil prices. The responsiveness toward change in imported crude oil price has increased by a factor of approximately 5 to 10 since Taiwan joined the WTO, indicating that globalization has intensified the effects of crude oil price fluctuations on production and daily life in Taiwan.

Although efforts have been made to advance technology and improve energy dependence, the empirical results of this study show the evidence that imported crude oil intensity and price responsiveness have actually increased. Thus, the speed of improvement in energy technology is insufficient to keep up with the extent of economic growth. During the period after the second oil crisis and before Taiwan joined the WTO, improvements in the savings of crude oil import inputs and the structural efficiency of domestic production decreased imported crude oil intensity and price responsiveness. In Taiwan, which lacks natural resources, economic development requires increased efficiency in domestic production and technology, in addition to savings on direct energy input. Although some progress was made in savings on imported crude oil input, the negative effects of the structural efficiency of production and domestic market demand substantially increased imported crude oil intensity and price responsiveness, again emphasizing the vulnerability of Taiwan's production.

\section{References}

[1] Hamilton, J. D., This is what happened to the oil price/macroeconomy relation. Journal of Monetary Economics, 38(2), pp. 215-220, 1996.

[2] Davis, S. J. and Haltiwanger, J., Sectoral job creation and destruction responses to oil price changes. Journal of Monetary Economics, 48(3), pp. 465-512, 2001.

[3] Lee, Kiseok and Ni, Shawn, On the dynamic effects of oil price shocks: a study using industry level data. Journal of Monetary Economics, 49(4), pp. 823-852, 2002. 
[4] Blanchard, O. J. and Gali, J., The macroeconomic effects of oil shocks: why are the 2000s so different from the 1970s? NBER Working Papers, No. 13368, 2007.

[5] Hamilton, J. D., What is an oil shock? Journal of Econometrics, 113(2), pp. 363-98, 2003.

[6] Hamilton, J. D., Nonlinearities and the macroeconomic effects of oil prices. Macroeconomic Dynamics, 15(3), pp. 364-378, 2011.

[7] Asadoorian, M. O., Eckaus, R. S. and Schlosser, C. A., Modeling climate feedbacks to electricity demand: the case of China, Energy Economics, 30, pp. 1577-1602, 2008.

[8] Ma, Hengyun, Oxley, Les, Gibson, J. and Kim, Bonggeun, China's energy economy: technical change, factor demand and interfactor/interfuel substitution. Energy Economics, 30, pp. 2167-2183, 2008.

[9] Lin, Boqiang and Jiang, Zhujun, Estimates of energy subsidies in China and impact of energy subsidy reform. Energy Economics, 33, pp. 273-283, 2011.

[10] Kilian, Lutz and Park, Cheolbeom, The impact of oil price shocks on the U.S. stock market. International Economic Review, 50(4), pp. 1267-1287, 2009.

[11] Fukunaga, Ichiro, Hirakata, Naohisa and Sudo, Nao, The effects of oil price changes on the industry-level production and prices in the United States and Japan in commodity prices and markets, NBER East Asia Seminar on Economics, University Chicago Press. 20, pp. 195-231, 2011.

[12] Gately, D. and Huntington, H. G., The asymmetric effects of changes in price and income on energy and oil demand. Energy Journal, 23(1), pp. 19-55, 2002.

[13] Adeyemi, O. I. and Hunt, L. C., Modeling OECD industrial energy demand: asymmetric price responses and energy-saving technical change. Energy Economics, 29, pp. 693-709, 2007.

[14] Inglesi-Lotz, R., The evolution of price elasticity of electricity demand in South Africa: a Kalman filter application. Energy Policy, 39, pp. 36903696, 2011.

[15] Neto, D., Testing and estimating time-varying elasticities of Swiss gasoline demand. Energy Economics, 34(6), pp. 1755-1762, 2012.

[16] Roy, J., Sanstad, A. H., Sathaye, J. A. and Khaddaria, R., Substitution and price elasticity estimates using inter-country pooled data in a translog cost model. Energy Economics, 28(5), pp. 706-719, 2006.

[17] Hickman, B. G., Huntington, H. G. and Sweeney, J. L., eds. (1987). Macroeconomic Impacts of Energy Shocks, North-Holland: Amsterdam.

[18] Beenstock, M., An econometric model of the oil importing developing countries. Economic Modelling, 12(1), pp. 3-14, 1995.

[19] Kim, I.-M., and Loungani, P., The role of energy in real business cycles. Journal of Monetary Economics, 29, pp. 173-189, 1992.

[20] De Miguel, C., Manzano, B. and Marín-Moreno, J. M., Oil price shocks and aggregate fluctuations. Energy Journal, 24(2), pp. 47-62, 2003. 
[21] Burbidge, J. and Harrison, A., Testing for the effects of oil-price rises using vector autoregressions. International Economic Review, 25(2), pp. 459-484, 1984.

[22] Mork, K. A., Oil and the macroeconomy when prices go up and down: an extension of Hamilton's results. Journal of Political Economy, 97, pp. 740-744, 1989.

[23] Mory. J. F., Oil prices and economic activity: is the relationship symmetric? Energy Journal, 14(4), pp. 151-161, 1993.

[24] Lee, K., Ni, S. and Ratti, R. A., Oil shocks and the macroeconomy: the role of price variability. Energy Journal, 16(4), pp. 39-56, 1995.

[25] Hooker, M. A., What happened to the oil price-macroeconomy relationship? Journal of Monetary Economics, 38, pp. 195-213, 1996.

[26] Bernanke, B. S., Gertler, M. and Watson, M., Systematic monetary policy and the effects of oil price shocks. Brookings Papers on Economic Activity 1, pp. 91-142, 1997.

[27] Balke. N. S., Brown, S. P. A. and Yücel, M. K., Oil price shocks and the U.S. economy: where does the asymmetry originate? Energy Journal, 23(3), pp. 27-52, 2002.

[28] Hamilton, J. D. and Herrera, A. M., Oil shocks and aggregate macroeconomic behavior: the role of monetary policy. Journal of Money, Credit and Banking, 36(2), pp. 265-291, 2004.

[29] Dalsgaard, T., Andre, C. and Richardson, P., Standard shocks in the OECDINTERLINK model. OECD Economics Department Working Papers, No. 306, ECO/WKP, 32, 2001.

[30] Hunt, B., Isard, P. and Laxton, D., The macroeconomic effects of higher oil prices. International Monetary Fund, IMF Working Paper, WP/01/14, 2001.

[31] Bohi, D. R., On the macroeconomic effects of energy price shocks. Resources and Energy, 13, pp. 145-162, 1991.

[32] Nagano, M., Increases in crude oil v. s. Japan/ eastern economies: The impact of price volatility on real sector. MRI Monthly Review, pp. 1-13, 2004 (in Japanese).

[33] Klein, L. R., Duggal, V. G. and Saltzman, C., The sensitivity of the general price level to change in the price of crude oil. Business Economics, 40(4), pp. 74-77, 2005.

[34] Ono, M., The impact of rising oil prices on the Japanese economy, Institute for International Trade and Investment, No. 60, 2005.

[35] Fuzikawa, K., Simota, M. and Watanabe, T., The spillover effect of imported crude oil price: evidences from U.S. and Japan. The Processing of the Japan Society of International Economics, 2007 (in Japanese). 